\title{
The Relationship between Shyness, Foreign Language Classroom Anxiety, Willingness to Communicate, Gender, and EFL Proficiency
}

\author{
Sam Bashosh \\ English Department, Shahid Bahonar University, Kerman, Iran \\ Mohammad Abbas Nejad \\ English Department, Shahid Bahonar University, Kerman, Iran \\ Mina Rastegar \\ English Department, Shahid Bahonar University, Kerman, Iran \\ Amin Marzban \\ English Department, Sepidan Branch, Islamic Azad University, Sepidan, Iran
}

\begin{abstract}
The present study aimed to examine the relationship found between shyness, foreign language classroom anxiety, willingness to communicate, gender, and EFL proficiency. To this end, sixty EFL undergraduates (40 females and 20 males) majoring in English Translation were selected through simple random sampling. Stanford Shyness Inventory by Zimbardo (1977), Foreign Language Classroom Anxiety Scale by Horwitz et al. (1986), and Willingness to Communicate Scale by McCroskey and Richmond (1987) were used to measure students' shyness, FLCA, and WTC respectively. Moreover, students' average score in their specialized courses were taken as a measure of their EFL proficiency. Analysis of the results showed that there is no significant relationship between shyness, foreign language classroom anxiety, willingness to communicate, gender, and EFL proficiency. The results have beneficial implications for teaching methodology and syllabus design.
\end{abstract}

Index Terms - shyness, foreign language classroom anxiety, willingness to communicate, gender, EFL proficiency

\section{INTRODUCTION}

Considerable variation has been observed in the rate of second language learning by individuals and in their ultimate language attainment. The reason is basically due to the complex nature of language which is affected by many variables, some of which are affective. Discussing affective variable in the realm of language learning and teaching is not a new trend. Inquiry in the psychological aspect of learning stems from arrival of humanistic psychology. Due to Rogers' and other humanistic theorists' works the effective side of human being received considerable attention (Pazouki, 2009). Humanistic psychology has also made its way into many fields ranging from building design to music, etc. (Arnold \& Brown, 1999).

According to Brown (2007), the concept of affect encompasses emotions and feelings and the development of affective states entails various personality factors. He believes that personality factors are the intrinsic side of affectivity which increases our success in language learning. Moreover, Schumann (1998) asserts that affective contributions act as key factors in language learning. Meanwhile, gender which is a physiological factor has its own impact on the language learning (Brown, 2000).

Most personality factors including shyness, willingness to communicate, foreign language anxiety, as well as gender that have an impact on language learning have been studied. The conflicting results of such studies were the motive behind carrying out the current research. The purpose of this study is to find out the relationship between the shyness, FLCA, WTC, gender, and EFL proficiency.

\section{PRevious StUdies}

\section{A. Shyness}

Shyness is one of the personality factors which has been widely researched and discussed in the literature (Chu, 2008). Some studies suggest that the common existence of shyness is intensifying (Carduci \& Zimbardo, 1995). Some view it as a form of social anxiety (Buss, 1980; Zimbardo, 1977), others view it as pattern of avoidant, reticent, and inhibited behavior (Phillips, 1980; Pilkonis, 1977a), still other researchers such as Croizer (1979), and Jones and 
Russell (1982) believe that it encompasses the both previously mentioned views. According to Saunders and Chester (2008), due to its breadth, it is difficult to define shyness. Shyness has been approached as a character trait, a state of inhibition and at times an attitude (Lewinsky, 1941). Pilkonis (1977a) defines it as propensity to keep away from appropriate participation in social situations. According to Buss (1985) it turns out to be some kind of uneasiness, inhibition, and gracelessness in social situations, particularly in situations dealing with unfamiliar people. Garcia et al. (1991) view shyness as a kind of worry and restraint in others attendance. Henderson and Zimbardo (1998a) define shyness as preoccupation with one's thoughts and reactions leading to lack of comfort in interpersonal context.

Hidden shyness while significant is an extreme concern with the so called self-presentation. Self-Presentation Theory is based on the assumption that in social and public contexts individuals try to take control of images of self or information related to identity (Stritzke, Nguyen, \& Durkin, 2004). Thus, individuals prefer to say nothing than to be disapproved or be rejected by others (Saunders \& Chester, 2008).

Shyness has been categorized differently by different researchers based on its gravity. Zimbardo (1977) classifies shyness into three subgroups: Individuals who are not after social interaction and prefer loneliness, individuals feeling unwilling to contact or get close to others, are socially unskilled and exhibit no self-confidence, and individuals who are concerned about violating social rules and others' expectations. Pilkonis (1977 a, b) distinguishes private shy from publically shy. Buss (1980), classifies shyness into fearful shy individual versus self-conscious shy individuals.

There are five reaction provoking situations which are distinctively associated with shyness: Interactions with authorities, one to one confrontation with the opposite gender, conversation with unidentified individuals, being focused by other persons in a small group, and situations in which a person is being evaluated in (Henderson \& Zimbardo, 1998a). According to Chu (2008), there is a moderately positive correlation found between shyness and FL anxiety. He also found a negative relationship between shyness and willingness to communicate in both first and second language. Also, some studies point to sex differences in shyness in adolescence (Saunders \& Chesters, 2008). According to Zimbardo, adolescent girls are slightly shyer than adolescent boys (1977).

Furthermore, with regard to language learning, Crozier (1997) documented that less shy children outperformed more shy ones in formal fluency and expressive vocabulary tasks. Besides, there was found to be a significant difference between shy and non-shy students regarding failing records (Amini, 1999). It was found that shy groups failed more than non-shy ones. Also, Sepehrband (2000) reported a better performance by non-shy students in comparison with the shy students. However, there was found no relationship between the two in a research done by Meftah (2002). Nevertheless, researches done by Allvar (2003), and Pazouki and Rastegar (2009) revealed the negative effect of shyness on the number and the type of strategies used by students, and on the language proficiency respectively.

\section{B. Foreign Language Anxiety}

Language anxiety is one of the main factors which influence language learning, no matter what the learning setting is (Oxford, 1999). Consideration of language learners' anxiety reactions is very important for a teacher if he/she is going to assist students in achieving the known performance goals in the intended target language (Tanveer, 2007), and also in developing communication skills (Hashemi, 2011). According to Cao (2011), anxiety is one of the widely observed affective factors in EFL/ESL learning. It is a psychological construct, usually described by psychologist as a feeling of apprehension, an implicit fear which is associated with an object only in an indirect way (Hilgard, Atkinson, \& Atkinson, 1971). It is a unique type of anxiety which is specific to foreign language learning (Horwitz et al., 1986). Besides, MacIntyre and Gardener (1994) described it as a state of tension specially related to the second language context containing skills such as speaking, listening, and learning.

Morris, Davis, and Hutchings (1981) classified anxiety as cognitive and somatic anxiety. Cognitive anxiety refers to mental aspect of anxiety such as negative expectation. Somatic anxiety refers to learners' perception of the psychological effect of the anxiety experience. Horwitz, Horwitz, and Cope (1986) proposed that FL anxiety has three components: communication apprehension, test anxiety, and fear of negative evaluation. Cheng (2004) has classified FL anxiety into cognitive, physiological, and avoidance behavior. Additionally, psychologists have made a distinction between three classes of anxiety: state anxiety, trait anxiety, and situation-specific anxiety (Hashemi, 2011). Trait anxiety is a more lingering personality characteristic while state anxiety is a temporary anxiety (Spielberg, 1983). Finally, the situation-specific anxiety refers to permanent nature of some kinds of anxieties (MacIntyre \& Gardner, 1991a).

There can be found various sources for language anxiety. It may stem from the persons' own self or from intrinsic motivators within social context (Shwartz, 1972; cited in Scovel, 1991). Moreover, Sparks and Ganschow believe that language anxiety may be a consequence as well as a source of inadequate grasp of language (Sparks \& Ganschow; cited in Horwitz, 2001). Regarding the effect of FLA on WTC, Chu (2008) found a negative effect of the first on the second factor. With regard to gender, Mejlas, Applebaum, and Trotter (1991) found a higher level of anxiety in males in comparison with females. However, studies done by Machida (2001), and Rezazadeh and Tavakoli (2009) showed the opposite results. Still, another study by Hussain, Shahid, and Zaman (2011) showed less anxiety among girls in comparison with boys.

Second language researchers and theorists have long been aware that anxiety is often associated with language learning (Horwitz, Horwitz, \& Cope, 1986). Growing number of the literature shows both facilitative and debilitative effect of anxiety. Some found positive relationship (Chastain, 1975; Kleinmann, 1977), others found a negative 
relationship (Horwitz, Horwitz, \& Cope,1986; Krashen, 1985; MacIntyre \& Gardner, 1989), still some believe that anxiety is probably an outcome of poor achievement in language learning, not the cause of it (Sparks, Ganschow, \& Javorsky, 2000).

\section{Willingness to Communicate (WTC)}

WTC is a basic acquisition concept in second language studies (MacIntyre, Clément, Dörnyei, \& Noels, 1998). MacIntyre et al. (1998) propose that the main goal of language instruction should be WTC. Dörnyei (2003) points out that, L2 competence by itself is not enough. Learners need both the ability and the willingness to communicate. The foundation of research on WTC refers back to Burgoon's (1976) study on being reluctant to communicate, Mortensen, Arntson, and Lustig's (1977) predisposition toward verbal behavior, and McCroskey and Richmond's (1982) conceptualization of shyness.

According to McCroskey and Baer (1985), WTC is the likelihood of engagement in communication when we have a free choice to do so. This definition limits WTC to a personality trait rather than situation based variables (MacIntyre et al., 1998). In fact, it is the predisposition to open conversation with others (McCroskey, 1997). Regarding the effective factors in WTC, researchers found communicative competence and communication anxiety to be significant predictors of WTC (MacIntyre, 1994; MacIntyre et al., 2001). Other individual differences, like previous immersion experience (MacIntyre et al., 2003a), sex and age (MacIntyre et al., 2003b), and attitudes toward the international community (Yashima et al, 2004), have also been found to influence WTC. There are several models that researchers have proposed in the WTC literature.

\section{McCroskey's Willingness-to-communicate Model}

Stemming from the early work of Philips (1965, 1968) on reticence, of Burgoon (1976) on unwillingness to communicate, and of Mortensen, Arntson, and Lustig (1977) on liability toward verbal behavior, the concept of Willingness to Communicate (WTC) was first presented by McCroskey and his associates (McCroskey \& Baer, 1985; McCroskey \& Richmond, 1987) with reference to L1 use and speaking as its focus. In this model, WTC is treated as a personality trait and defined as a tendency to start the conversation. McCroskey and McCroskey (1986a) found the negative relationship between L1 WTC and communication apprehension, introversion, alienation, and anomie.

Moreover, they also found a positive relationship between WTC, self-esteem and communication competence perceived by individuals (McCroskey \& McCroskey, 1986a). Additionally, Chan and McCroskey (1987) asserted that WTC has a positive effect on the verbal participation of students in the classroom.

\section{E. Clement's and MacIntyre's Willingness-to-communicate Models}

In contrast with the above-mentioned view of McCroskey, other researchers found it inadequate to treat WTC as a trait-like attribute. They argued that WTC could be situation-specific and that it's not transferrable from L1to L2. Clement and MacIntyre are proponents of this view.

\section{F. Clement's Social Context Model (Clement, 1980; Clement \& Kruidenier, 1985)}

In this model, the emphasis is on the association between intergroup contacts, L2 confidence, L2 competence, and L2 identity. The model suggests that the quality and frequency of approaches with the EFL/ESL community is the source of variations in L2 confidence, which is composed of perceived communicative competence and lower levels of L2 anxiety. In addition, there found to be a link between L2 confidence and growth of L2 communication competence, better identification with the L2 community, and increase in assimilation motive (Clement et al., 2003; Noels \& Clement, 1996). However, this model is not concerned with L2 usage.

\section{G. Heuristic Model of Variables Influencing WTC}

Based on Clement's Social Context Model, MacIntyre and his colleagues (MacIntyre, Dornyei, Clement, \& Noels, 1998) argued that WTC should be treated as a situational variable that can be affected by linguistic, communicative, social, and psychological factors, the group that he or she belongs to, and the L2 community. So, they presented a heuristic model of variables influencing WTC in which both proximal and distal causes that affect individual's variation in WTC are included. The model has six layers, with the top three being situation-specific and the bottom three more enduring. L2 use (layer 1), willingness to communicate (layer 2), and tendency to communicate with particular individuals and state communicative self-confidence (layer 3) are situation-specific influences. More persisting effects include interpersonal and between-group motivations and L2 self-confidence (layer 4), Intergroup reactions, social context and communicative competence (layer 5), and intergroup atmosphere and personality (layer 6). In this model, the most immediate antecedents for WTC are the eagerness to communicate with a specific people and state communicative self-confidence.

\section{METHOD}

\section{A. Participants}


The participants for this study included 60 undergraduates (40 females and 20 males) of English Translation at Shahid Bahonar University of Kerman who were selected through simple random sampling. They were also homogenized through the Oxford Placement Test (OPT) as far as language proficiency was concerned.

\section{B. Instruments}

Shyness: in order to measure the amount of shyness in the participants, Stanford Shyness Inventory was used. This inventory has been first developed by Zimbardo at Stanford University in 1977. The original form consisted of 44 items. In order to make it compatible with the cultural setting in Iran (Pazouki, 2005), the inventory had been modified and reduced to 40 items. Each item which was expressed in the form of a statement had four choices as possible answers, each of which indicated a degree in shyness. From the lowest to the highest degree, each item received 1, 2, 3, and 4 scores. So, the range of scores was from 40 (the least shy) to 160 (the shyest) (Pazouki, 2005). The reliability of the test for boys was 0.82 and for girls was 0.86 and for the whole population was 0.84 which is quite satisfactory.

Foreign Language anxiety: Horwitz et al.'s (1986) 'Foreign Language Classroom Anxiety Scale' was used to determine the students' foreign language anxiety level. This is a Likert scale including 33 items which has students respond to situations and contexts that are exclusive to foreign language learning anxiety. This scale reflected three constituting parts of foreign language anxiety; namely, communication apprehension, anxiety in tests, and fear of being negatively evaluated (Ganschow \& Sparks, 1996). Responses ranged from strongly agree to strongly disagree. For every single item, the highest level of anxiety scores five and the lowest, one point. Students' scores ranged from 33 to 165. The internal consistency of the scale was 0.93 and its reliability was 0.83 (Horwitz, 1986).

Willingness to Communicate: willingness to Communicate Scale (McCroskey \& Richmond, 1987) was utilized to assess willingness to communicate in the students. It is a 20 -item scale, 8 of which are fillers and the remaining 12 are scored as part of the scale. The 12 items on the scale show the crossing of three kinds of receivers (i.e. acquaintances, strangers, and friends) with four communication context types (group, public, meeting, and dyad). For each item to be answered, students had to indicate the percentage of their eagerness to communicate in the specified situation ranging from 0 to a 100 percent. To compute the total WTC scores, the sub-scores for stranger, acquaintance, and friend were added and then divided by 3 . The estimates of internal reliability of the total score on the instrument ranged from 0.86 to 0.95 with a modal estimate of 0.92 (McCroskey, 1992).

\section{FINDINGS}

The finding of this research showed no relationship between shyness, foreign language anxiety, willingness to communicate, gender, and foreign language proficiency. Upon analysis of the obtained data with SPSS (version 18) the following results were found.

\section{A. Descriptive Statistics}

In order to demonstrate the correlation and difference between several factors involved in language learning in the current study, descriptive statistics were run. As Table 1 shows, the descriptive results for the 4 factors of shyness, Foreign Language Classroom Anxiety (FLCA), Willingness to Communicate (WTC) along with Gender and EFL Proficiency (GPA) exhibits distinct means for all the factors. This would lay further proof on the fact that EFL learners' performance in each category may act independently from the remaining factors.

TABLE I

THE DISCRIPTIVE STATISTICS

\begin{tabular}{|l|l|l|l|l|l|l|}
\hline & $\mathrm{N}$ & Range & Minimum & Maximum & Mean & Std. Deviation \\
\hline EFL Proficiency & 60 & 6.05 & 12.90 & 18.95 & 15.997 & 1.332 \\
WTC & 60 & 92.00 & 6.00 & 98.00 & 23.966 & 12.105 \\
FLCA & 60 & 57.00 & 60.00 & 117.00 & 84.000 & 16.295 \\
Shyness & 60 & 640.00 & 66.00 & 706.00 & 96.633 & 80.580 \\
Valid N (listwise) & 60 & & & & & 1.776 \\
\end{tabular}

\section{B. Shyness and FLCA}

In order to analyze the relationship between each pair of the factors, the correlation coefficient between two of them (i.e. FLCA and shyness) was checked.

TABLE II

CORRELATION MATRIX

\begin{tabular}{|c|c|c|c|c|}
\hline & Shyness & FLCA & WTC & EFL proficiency \\
\hline Shyness & 1.000 & .320 & .130 & .313 \\
\hline FLCA & .320 & 1.000 & .695 & .811 \\
\hline WTC & .130 & .695 & 1.000 & .749 \\
\hline EFL Proficiency & .313 & .811 & .749 & 1.000 \\
\hline
\end{tabular}

As Table 2 shows, the significance value of 0.320 is higher than 0.05 . This means that there is no significant relationship between the two factors. 


\section{Shyness and WTC}

In order to analyze the relationship between another pair of the factors, the correlation coefficient between a different pair of factors (i.e. shyness and WTC) was checked. As can be seen in Table 2, the value of Sig= 0.130 shows no significant relationship between shyness and willingness to communicate.

\section{Shyness and Gender}

In order to analyze the relationship between another pair of the factors, the correlation coefficient between gender and shyness was checked. Table 3 shows a series of independent samples t-tests from which it can be seen that there is no significant relationship between shyness and gender as the value of $\mathrm{Sig}=0.442$ further clarifies the point.

TABLE III.

INDEPENDENT SAMPLES T-TEST

\begin{tabular}{|c|c|c|c|c|c|c|c|c|c|}
\hline & \multicolumn{2}{|c|}{$\begin{array}{l}\text { Levene's Test for } \\
\text { Equality of } \\
\text { Variances }\end{array}$} & \multicolumn{7}{|c|}{ t-test for Equality of Means } \\
\hline & \multirow[t]{2}{*}{$\mathrm{F}$} & \multirow[t]{2}{*}{ Sig } & \multirow[t]{2}{*}{$\mathrm{t}$} & \multirow[t]{2}{*}{$\mathrm{df}$} & \multirow[t]{2}{*}{$\begin{array}{l}\text { Sig } \\
(2 \text {-tailed })\end{array}$} & \multirow[t]{2}{*}{$\begin{array}{l}\text { Mean } \\
\text { difference }\end{array}$} & \multirow[t]{2}{*}{$\begin{array}{l}\text { Std. Error } \\
\text { differences }\end{array}$} & \multicolumn{2}{|c|}{$\begin{array}{l}95 \% \text { confidence } \\
\text { interval of the difference }\end{array}$} \\
\hline & & & & & & & & Lower & Upper \\
\hline $\begin{array}{cc}\text { GPA } & \begin{array}{c}\text { Equal variances } \\
\text { assumed }\end{array} \\
\end{array}$ & \multirow[t]{2}{*}{.436} & \multirow[t]{2}{*}{.511} & 1.304 & 58 & .197 & .473 & .362 & -.253 & 1.199 \\
\hline $\begin{array}{l}\text { Equal variances } \\
\text { not assumed }\end{array}$ & & & 1.356 & 42.341 & .182 & .473 & .348 & -.230 & 1.176 \\
\hline $\begin{array}{cc}\text { WTC Equal variances } \\
\text { assumed }\end{array}$ & \multirow[t]{2}{*}{2.550} & \multirow[t]{2}{*}{.116} & 1.211 & 58 & .231 & 4.000 & 3.302 & -2.609 & 10.609 \\
\hline $\begin{array}{c}\text { Equal variances } \\
\text { not assumed }\end{array}$ & & & 1.554 & 56.184 & .126 & 4.000 & 2.573 & -1.155 & 9.155 \\
\hline $\begin{array}{cc}\text { FLCA Equal variances } \\
\begin{array}{c}\text { assumed } \\
\text { and }\end{array}\end{array}$ & \multirow[t]{2}{*}{4.266} & \multirow[t]{2}{*}{0.43} & 1.600 & 58 & 115 & 7.050 & 4.404 & -1.767 & 15.867 \\
\hline $\begin{array}{l}\text { Equal variances } \\
\text { not assumed }\end{array}$ & & & 1.758 & 48.824 & .085 & 7.050 & 4.009 & -1.008 & 15.108 \\
\hline $\begin{array}{c}\text { Shyness Equal variances } \\
\text { assumed }\end{array}$ & \multirow[t]{2}{*}{1.333} & \multirow[t]{2}{*}{.253} & .775 & 58 & .442 & 17.150 & 22.143 & -27.174 & 61.474 \\
\hline $\begin{array}{l}\text { Equal variances } \\
\text { Not assumed }\end{array}$ & & & 1.095 & 39.980 & .280 & 17.150 & 15.664 & -14.509 & 48.809 \\
\hline
\end{tabular}

\section{E. Shyness and Language Proficiency}

The next relationship focused on checking two more factors of shyness and EFL proficiency. The results are summarized in Table 2. As Table 2 shows, no significant relationship was found between shyness and EFL proficiency, since the value of $\mathrm{Sig}=0.313$ is higher than 0.05 .

\section{F. Foreign Language Classroom Anxiety and WTC}

Regarding the connection between FLA and WTC, no significant relationship was found. As Table 2 shows, in this case $\mathrm{Sig}=0.695$ which is higher than $\alpha(\mathrm{Sig}>\alpha)$ implies a non-significant relationship between these two factors.

\section{G. Foreign Language Classroom Anxiety and Gender}

Table 3 illustrates that there is no significant relationship between the two factors of gender and classroom anxiety. It can be seen in independent samples t-test results (i.e. $\mathrm{Sig}=0.085$ ).

\section{H. Foreign Language Classroom Anxiety and Language Proficiency}

A further analysis of the relationship between classroom anxiety and language proficiency also exhibited nonsignificance. As Table 2 shows, there is no significant relationship between FLCA and language proficiency ( $\mathrm{Sig}=$ 0.811 i.e. $\operatorname{Sig}>\alpha$ ).

\section{WTC and Gender}

Table 3 illustrates that there found to be no significant relationship between WTC and gender. (Here Sig=0.231, so $\operatorname{Sig}>\alpha)$.

\section{J. WTC and Language Proficiency}

Table 2 describes the relationship between WTC and language proficiency. As it can be realized from Table 2, the relationship between the two mentioned factors is not significant, because $\mathrm{Sig}=0.749$ i.e. $\mathrm{Sig}>\alpha$.

\section{K. Gender and Language Proficiency}

Like the relationship between other factors in this research, as it is shown in Table 3, no significant relationship was found between gender and language proficiency.

\section{DisCUSSION AND CONCLUSION}


The present study has pointed towards the relationship between four different influential factors in learning; namely, shyness, FLCA, WTC, gender, and EFL proficiency. Regarding the relationship between shyness and FLCA, and shyness and WTC, the result of the study showed no significant relationship between these factors which is in contrast with the findings of Chu (2008) who found a moderately positive relationship between shyness and FLCA, and a negative relationship between shyness and WTC.

Also, unlike studies by Saunders \& Chesters (2008) who reported sex differences in shyness in adolescence and Zimbardo (1977) who found that adolescent females were mildly shyer than adolescent boys, the finding of this study showed a non-significant relationship between shyness and gender.

Regarding shyness and language proficiency, the finding of this study is supported by Meftah (2002) who found no relationship between the two factors. However, it contrasts with the findings of Crozier (1997), Sepehrband (2000), and Amini (1999) who reported better performance of non-shy students in comparison with the shy one's.

Moreover, in the case of FLCA and WTC, no significant relationship was found. This finding disagrees with the result of a study by Chu (2008), who found a negative relationship between the two factors. Also, contrary to the findings of Mejlas, Applebaum, and Trotter (1991) who found a higher level of anxiety in males in comparison with females, and Machida (2001), and Rezazadeh and Tavakoli (2009) who showed more anxiety in females in comparison with males, this study showed no significant relationship between the two factors.

With regard to FLCA and EFL proficiency, it was found that the relationship is not significant based on the results of this study. However, this is not in line with the findings of Kleinmann (1977) who found a positive and Krashen (1985) who found a negative relationship between the two factors. Similarly, no significant relationship was found between WTC and gender, WTC and language proficiency, and gender and language proficiency.

Finally, the present study suffered from a number of limitations, two of which are addressed here. First, the small number of participants $(\mathrm{N}=60)$ may have affected the result of the study. However, it was impossible to address a larger group of participants due to manageability concerns. Second, although the participants in this study were homogenized through the oxford placement test, the average level of Iranian EFL proficiency level may have diversely influenced the result of this piece of research since language proficiency of most Iranian L2 learners is generally lower that the global standard.

\section{ApPendiX A. Foreign Language Classroom AnXIETy ScAle (HorwitZ ET AL., 1986)}
1..Strongly agree
2. Agree
3. Neither agree nor disagree
4. Disagree
5.Strongly disagree

1. I never feel quite sure of myself when I am speaking in my foreign language class.

2. I don't worry about making mistakes in language class.

3. I tremble when I know that I'm going to be called on in language class.

4. It frightens me when I don't understand what the teacher is saying in the foreign language.

5. It wouldn't bother me at all to take more foreign language classes.

6. During language class, I find myself thinking about things that have nothing to do with the course.

7. I keep thinking that the other students are better at languages than I am.

8. I am usually at ease during tests in my language class.

9. I start to panic when I have to speak without preparation in language class.

10. I worry about the consequences of failing my foreign language class.

11. I don't understand why some people get so upset over foreign language classes.

12. In language class, I can get so nervous I forget things I know.

13. It embarrasses me to volunteer answers in my language class.

14. I would not be nervous speaking the foreign language with native speakers.

15. I get upset when I don't understand what the teacher is correcting.

16. Even if I am well prepared for language class, I feel anxious about it.

17. I often feel like not going to my language class.

18. I feel confident when I speak in foreign language class.

19. I am afraid that my language teacher is ready to correct every mistake I make.

20. I can feel my heart pounding when I'm going to be called on in language class.

21. The more I study for a language test, the more confused I get.

22. I don't feel pressure to prepare very well for language class.

23. I always feel that the other students speak the foreign language better than I do.

24. I feel very self-conscious about speaking the foreign language in front of other students.

25. Language class moves so quickly I worry about getting left behind.

26. I feel more tense and nervous in my language class than in my other classes.

27. I get nervous and confused when I am speaking in my language class.

28. When I'm on my way to language class, I feel very sure and relaxed.

29. I get nervous when I don't understand every word the language teacher says.

30. I feel overwhelmed by the number of rules you have to learn to speak a foreign language.

31. I am afraid that the other students will laugh at me when I speak the foreign language.

32. I would probably feel comfortable around native speakers of the foreign language.

33. I get nervous when the language teacher asks questions which I haven't prepared in advance. 
Directions: Below are twenty situations in which a person might choose to communicate or not to communicate. Presume you have completely free choice. Indicate the percentage of times you would chose to communicate in each type of situation. Indicate at the space in the right what present of the time you would chose to communicate.

$0=$ Never $\quad 100=$ Always

1. Talk with a service station attendant.

2. Talk with a physician.

3. Present a talk to a group of strangers

4. Talk with an acquaintance while standing in line.

5. Talk with a sales person in a store.

6. Talk in a large meeting of friend.

7. Talk with a police officer.

8. Talk in a small group of strangers.

9. Talk with a friend while standing in line.

10. Talk with a waiter/waitress in a restaurant.

11. Talk in a large meeting of acquaintances.

12. Talk with a stranger while standing in line.

13. Talk with a secretary.

14. Present a talk to a group of friends.

15. Talk in a small group of acquaintances.

16. Talk with a garbage collector.

17. Talk in large meeting of strangers.

18. Talk with a spouse (or girl/ boyfriend).

19. Talk in a small group of friends.

20. Present a talk to a group of acquaintances.

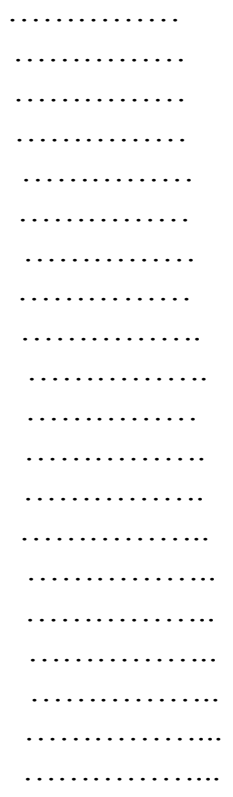

\section{REFERENCES}

[1] Allvar, N. K. (2003). The relationship between shyness, elicitation task nature and Iranian EFL students' use of oral communication strategies. (Unpublished master's thesis). T.M.U., Tehran.

[2] Amini, S. (1999). Investigating the prevalence and causes of shyness in female third graders of guidance schools in Shahriar. (Unpublished master's thesis). Islamic Azad University, Tehran.

[3] Arnold, J., \& Brown, H. D. (1999). A map of the terrain. In J. Arnold (Ed.), Affect in language learning. (pp. 1-27). Cambridge: Cambridge University Press.

[4] Brown, H. D. (2000). New vistas: Book 3. White Plains, NY: Pearson Education.

[5] Brown, H. D. (2007). Principles of language learning and teaching $\left(5^{\text {th }}\right.$ ed.). White Plains, NY: Pearson Education.

[6] Burgoon, j. K. (1976). The unwillingness to communicate scale: Development and validation. Communication Monographs, 43, 60-69.

[7] Buss, A. H. (1980). Self-consciousness and social anxiety. San Francisco: Freeman.

[8] Cao, Y. (2011). Comparison of two models of foreign language classroom anxiety scale. Philippine ESL Journal, 7, 73-93.

[9] Carducci, B. J., \& Zimbardo, P. (1995). Are you shy? Psychology Today, 64, 34-40.

[10] Chan, B., \& McCroskey, j. C. (1987). The WTC scale as a predictor of classroom participation. Communication Research Reports, 4, 47-50.

[11] Chastain, K. (1975). Affective and Ability Factors in Second Language Acquisition. Language Learning, 25, 153-161.

[12] Cheng, Y. S. (2004). A measure of second language writing anxiety. A Journal of Second Language Writing, 13, 313-335.

[13] Chu, H. R. (2008). Shyness and EFL Learning in Taiwan: A Study of Shy and Non-shy College Students' Use of Strategies, Foreign Language Anxiety, Motivation, and willingness to communicate. (Doctoral Dissertation). Retrieved from www.proquest.com (accessed 29/2/2012).

[14] Clément, R. (1980). Ethnicity, contact and communicative competence in a second language. In H. Giles, W. P. Robinson \& P. M. Smith (Eds.), Language: Social psychological perspectives (pp.147-154). Oxford, England: Pergamon Press.

[15] Clément, R., Baker, S. C., \& MacIntyre, P. D. (2003). Willingness to communicate in a second language: The effects of context, norms, and vitality. Journal of Language and Social Psychology, 22(2), 190-209.

[16] Croizer, W. R. (1979). Shyness as a dimension of personality. British Journal of Social \& Clinical Psychology, 18(1), 121-128.

[17] Crozier, W. R. (1997). Individual learners: Personality differences in education. NY: Routledge.

[18] Dörnyei, Z. (2003). Attitudes, orientations, and motivations in language learning: advances in theory, research, and applications. Language Learning, 53, 3-32.

[19] Garcia, S., Stinson, L., Ickes, W., Bissonnette, V., \& Briggs, S. R. (1991). Shyness and physical attractiveness in mixes -sex dyads. Journal of Personality and Social Psychology, 61, 35-49.

[20] Hashemi, M. (2011). Language stress and anxiety among the English language learners. Procedia - Social and Behavioral Sciences, 30, $1811-1816$.

[21] Henderson, L., \& Zimbardo, P. (1998a). Encyclopedia of Mental Health. San Diego: Academic Press.

[22] Hilgard, E. R., Atkinson, R. C., \& Atkinson, R. L. (1971). Introduction to psychology (5th ed.). New York: Harcourt.

[23] Horwitz, E. (1986). Preliminary evidence for the reliability and validity of a foreign language anxiety scale. TESOL Quarterly, 20, 559-564.

[24] Horwitz, E. K., Horwitz, M. B., \& Cope, J. A. (1986). Foreign language classroom anxiety. The Modern Language Journal, 70 (2), 125-132. 
[25] Horwitz, E. K. (2001). Language anxiety and achievement. Annual Review of Applied Linguistics, 21, 112-126.

[26] Hossein, M. A., Shahid, S., \& Zaman, A. (2011). Anxiety and attitude of secondary school students towards foreign language learning. Procedia Social and Behavioral Sciences, 29, $583-590$.

[27] Jones, W. H., \& Russell, D. (1982). The social reticence scale: An objective instrument to measure shyness. Journal of personality assessment, 46(6), 629-631.

[28] Kleinmann, H. (1977). Avoidance behavior in adult second language acquisition. Language Learning, 27, 93-107.

[29] Krashen, S. (1985). The Input Hypothesis. London: Longman.

[30] Lewinsky, H. (1941). The nature of shyness. British Journal of Psychology, 32,105-113.

[31] Machida, S. (2001). Anxiety in Japanese-language class oral examinations. Sekai no Nihongo Kyoiku, 11,115-138.

[32] MacIntyre, P. D., \& Gardner, R. C. (1989). Anxiety and second language learning: Toward a theoretical clarification. Language Learning, 39, 251-275.

[33] MacIntyre, P., \& Gardner, R. (1991a). Investigating language class anxiety using the focused essay technique. Modern Language journal, 75, 296-304.

[34] MacIntyre, P., \& Gardner, R. (1994). The subtle effects of language anxiety on cognitive processing in the second language. Language Learning, 44, 283-305.

[35] MacIntyre, P. D., Clément, R., Dörnyei, Z., \& Noels, K. A. (1998).Conceptualizing willingness to communicate in a L2: A situational model of L2 confidence and affiliation. The Modern Language Journal, 82(IV), 545-562.

[36] MacIntyre, P. D., Baker, S. C., Clement, R., \& Conrod, S. (2001). Willingness to communicate, social support, and languagelearning orientations of immersion students. Studies on Second Language Acquisition, 23, 369-388.

[37] MacIntyre, P. D., Baker, S. C., \& Clément, R. (2003b). Sex and age effect on willingness to communicate, anxiety, perceived competence, and L2 motivation among junior high school French immersion students. Language Learning, 53(3), 137-165.

[38] McCroskey, J. C. (1977). Oral communication apprehension: A summary of recent theory and research. Human Communication Research, 4, 78-95.

[39] McCroskey, J. C., \& Richmond, V. P. (1982). Communication apprehension and shyness: Conceptual and operational distinctions. Central States Speech Journal, 33, 458-468.

[40] McCroskey, J. C., \& Baer, J. E. (1985). Willingness to communicate: The construct and its measurement. Paper presented at the annual convention of the Speech Communication Association, Denver, Colorado.

[41] McCroskey, j. C, \& McCroskey, L. L. (February, 1986a). Correlates of willingness to communicate. Paper presented at the Western Speech Communication Association, Tucson, AZ.

[42] McCroskey, J. C., \& Richmond, V. P. (1987). Willingness to communicate. In J. C. McCroskey \& J. A. Daly (Eds.), Personality and interpersonal communication (pp. 129-156). Newbury Park, CA: Sage.

[43] McCroskey, J. C. (1992). Reliability and validity of the willingness to communicate scale. Communication Quarterly, 40, 1625.

[44] Mejías, H., Applebaum, R. L., Applebaum S. J. \& Trotter, R. T. (1991). Oral Communication apprehension and Hispanics: An exploration of oral communication apprehension among Mexican American students in Texas. In E. Miller, R.S. (1995). On the nature of embarrassability: Shyness, social evaluation and social skill. Journal of Personality, 63, 315-339.

[45] Morris, L. W., Davis, M. A., \& Hutchings, C. H. (1981). Cognitive and emotional components of anxiety: Literature review and a revised worry emotionality scale. Journal of Educational Psychology, 73, 541-555.

[46] Mortenson, C. D., Arnston, P. H., \& Lustig, M. W. (1977). Measurement of verbal predispositions: Scale development and application. Human Communication Research, 3, 146-158.

[47] Noels, K. A., Pon, G., \& Clement, R. (1996). Language, identity, and adjustment: The role of linguistic self-confidence in the acculturation process. Journal of Language and Social Psychology, 15, 246-264.

[48] Oxford, R. L. (1999). Anxiety and the language learner: New insights. In J. Arnold (Ed.), Affect in language learning (pp. 5867). Cambridge: Cambridge University Press.

[49] Pazooki, M., \& Rastegar, M. (2009). Extraversion-Introversion, shyness, and EFL proficiency. Psychological Research, 12 (1\&2), 78-91.

[50] Pazuoki, M. (2005). The relationship between extraversion-introversion, shyness, and EFL Proficiency. (M.A thesis). Shahid Bahonar University of Kerman: Kerman.

[51] Pilkonis, P. A. (1977a). Shyness, public and private and its relationship to other measures of social behavior. Journal of Personality, 45(4), 585-595.

[52] Pilkonis, P. A. (1977b). The behavioral consequences of shyness. Journal of personality, 45(4), 596-611.

[53] Rezazadeh, M., \& Tavakoli, M. (2009). Investigating the relationship among test anxiety, gender, academic achievement and years of study: A case of Iranian EFL university students. English Language Teaching, 2(4). 68-74.

[54] Saunders, P. L., \& Chester, A. (2008). Shyness and the internet: Social problem or panacea? Computers in human behavior, 24, 2649-2658.

[55] Schumann, J. (1998). The neurobiology of affect in language. Language Learning, 48 (Suppl. 1).

[56] Scovel, T. (1991). 'The effect of affect on Foreign language learning: A review of the anxiety research', in Horwitz, E.K., \& Young, D. J. (eds.) Language Anxiety: From Theory and Research to Classroom Implications (pp. 15-24). Englewood Cliffs, NJ: Prentice Hall.

[57] Sepehrband, M. (2000). The relationship between shyness and Iranian guidance school students' language achievement. (Unpublished master's thesis). Tehran: T.M.U.

[58] Sparks, R., Ganschow, L., \& Javorsky, J. (2000). Deja Vu all over again: A response to Saito, Horwitz, and Garza. Modern Language Journal, 84, 251-255.

[59] Spielberger, C. (1983). Manual for the state-trait anxiety inventory Palo Alto. CA: Consulting Psychologists Press.

[60] Stritzke, W. G., Nguyen, A., \& Durkin, K. (2004). Shyness and computer-mediated communication: A self-presentational theory perspective. Media Psychology, 6, 1-22. 
[61] Tanveer, M. (2007). Investigation of the factors that cause language anxiety for ESL/EFL learners in learning speaking skills and the influence it casts on communication in the target language. (Unpublished thesis). Faculty of education, University of Glasgow.

[62] Yashima, T., Zenuk-Nishide, L., \& Shimizu, K. (2004). The influence of attitude and affect on willingness to communicate and second language communication. Language Learning, 54, 119-152.

[63] Zimbardo, P. G. (1977). Shyness: what it is, what to do about it. Reading, MA: Addison-Wesley.

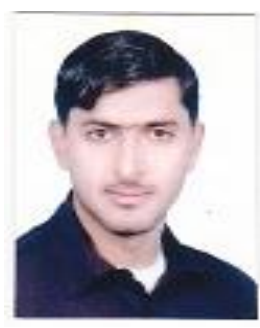

Sam Bashosh received his B.A. in English Translation from Islamic Azad University of Shiraz, Fars, Iran, in 2009. At present, he is an M. A. student in TEFL and he is working on his M.A. thesis project. He is, also, teaching general and special courses of English in Islamic Azad University of Bandar-e- Khamir. His areas of interest include psycholinguistic, morphology, and teaching methodology.

Mohammad Abbas Nejad received his Ph.D. in TEFL from Allameh Tabatabaei University of Tehran and is currently an assistant professor in the language department of the University of Kerman. He, also, works as a member of NAATI accredited translator as well as Iranian Society of Official Translators. He has been teaching general and specific courses of English in different universities since 1992. Moreover, he has published many articles in different journals. His areas of interest include morphology, ESP, and applied linguistics.

Mina Rastegar, an Assistant Professor of Language and Applied Linguistics in the language department of the University of Kerman for the last 26 years. She holds Ph. D degree in TEFL. Her professional expertise lies in the area of Psycholinguistics. Her research focuses on L2 learner factors - affective, cognitive, and personality. Dr. Rastegar is currently teaching research methods, methodology, testing, and advanced writing at both B.A and M.A levels.

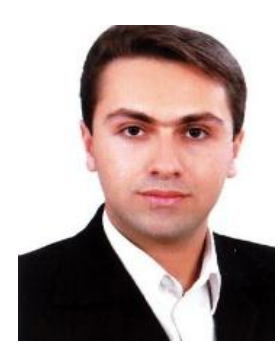

Amin Marzban received his Ph.D. in applied linguistics from the University of Isfahan and is currently an assistant professor in TEFL at Islamic Azad University. He also works as a member of board of editors in some journals such as IJLLALW. He has been teaching major and non-major courses at state and Azad universities over the past decade and has been continuously publishing in popular journals. His areas of interest include teaching methodology and psycholinguistics. 